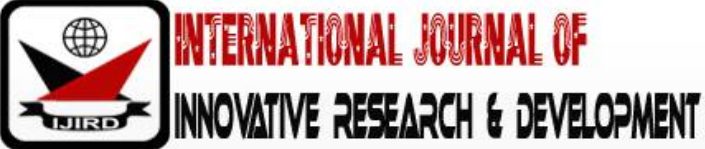

ISSN 2278-0211 (Online)

\section{Library and Information Science Lecturers' Perception of Generating Resources for Attaining Sustainable Development Goals in Anambra State, Nigeria}

\begin{tabular}{c}
\hline Ndanwu, Angela I. \\
Librarian Head, Department of Circulation, Nnamdi Azikiwe University, Awka, Nigeria \\
Anaehobi, Egbuna .S. \\
Deputy Librarian, Department of Library and Information Science, \\
Nnamdi Azikiweuniversity, Awka, Nigeria \\
Onwudinjo, O.T.U \\
Lecturer, Department of Law Librarian, Nnamdi Azikiwe University, Awka, Nigeria \\
\hline
\end{tabular}

\begin{abstract}
:
The paper discusses the perception of Library and Information Science lecturers on how to generate human and material resources for the attainment of Sustainable Development Goals (SDGs) in Anambra State. It equally discussed the implementation strategies and envisaged barriers to SDGs. The study was done in all the Federal tertiary schools in Anambra State. Data for the study was collected by means of questionnaire administered to lecturers in the specified institutions. The questionnaire was validated and reliability of 0.86 was computed using Cronbach Alpha. Data collected were analysed using mean and chi square. LIS lecturers perceive, among other things that human resources are yet to be prepared for the attainment of SDGs. It was recommended that standard workstation, should be established in the tertiary institutions.
\end{abstract}

Keywords: Lecturer's perceptions, development goals, human resources, material resources, library and information science

\section{Introduction}

The global partnership emerging goals which has become a household name in the context of social, economic, environmental and political reform have led to nations redefining their priorities in order to enhance productivity and hence compete effectively and efficiently in the emerging global society. One of the goals that has become prominent in the global reform context is the Sustainable Development Goals (SDGs), which replaced the Millennium Development Goals (MDGs). SDGs were born at the 2015 Annual African Network for Internationalization of Education (ANIE) conference in Darussalam, Tanzania.

Some of the United Nations Sustainable Development Goals for the period of 2015 - 2030 that succeeded the Millennium Development Goals on January 1, 2016 which is to be achieved by 15 years are as follows: Ensure inclusive and equitable quality education and promote life- long learning opportunities for all; Achieve gender equality and empower all women and girls, Build resilient infrastructure, industrialization and foster innovation(Adegbulu, N.D).

This topic was positioned with the $4^{\text {th }}$ global goals where it stipulated the role of the education system in sustainable development as the goal of providing inclusive and equitable education and lifelong learning opportunities for all people (SDG4). There are many opportunities for universities to collaborate on teaching, research and information exchange, and dissemination. This should be done through well supported, coordinated academic environment.

Library and information science lecturers need to be relevant in Nigeria's efforts in working towards the attainment of the SDGs through active collaboration with the relevant government and non-governmental agencies with mandate related to each of the 17 goals. As the basic focus of SDGs are to end or eradicate poverty, protect the planet, ensure prosperity for all and sundry and also transform the world. There is need to revisit the school curriculum and its implementation. To achieve the goals and objectives of SDGs, there is need for orientation by government to help lecturers manipulate and teach the new curriculum, apply learning that can make a real difference to learners. Egron-Polak (key speaker), while speaking during the UNESCO International Institute for Educational Planning Strategy debate stated that 'Higher Education Institutions need to be both better informed and mobilized to engage in the overall SDGs agenda and Education 2030'. Egron-Polak in IIEP-UNESCO (2016) further said that Education2030 framework for implementing SDGs 4 , stresses the interdependency of all education levels, from pre-primary through to higher education and formal and nonformal education. Curriculum Relevance refers to applicability and appropriateness of a curriculum to the needs, interest, 
aspirations, and expectations of learners and society in general (International Bureau of Education, 2017). This curriculum is in fact the warp and woof of the whole educational process (Dushi 2012). The dominant view of curriculum relevance is for curriculum content to be sensitive to the needs, goals and aspirations of the students. Ogbuigwe (2017) opined that SDGs is a comprehensive platform, to finally transform higher education in Africa to deal with fundamental issues that have held us down, such as poverty, hunger, environmental degradation, an excessive consumption of unproductive education, goods, debt burden, market inaccessibility, technology, governance challenges, and public health issues like HIV/AIDS, malaria, measles and malnutrition.

The sustainable Development Goals succeeded Millennium Development Goals. Quality education induced with material resources are enabler of attainment of these global goals. Quality education must, however be combined with the widest access possible in order to make significant impact, especially in developing countries like Nigeria, where millions are under-served by traditional education system. Supporting lecturer's activities by connecting them to vast array of human and material resources such as facilities, laboratories, ICT tools, textbooks, electronic devices whether wholly or in part, for course delivery will lead to better teaching, learning process and attainment of SDGs Course delivery is tantamount to teaching and learning (Ayomike, Okwelle\&Okeke, 2015). Meanwhile, SDGs are global goals that someone aimed to be achieved by 2030. On this note, certain implementation strategies ought to be planned/mapped out by Nigerian Educational Research Development Council (NERDC). These strategies includes training and retraining and mentoring of lecturers, with modern ICT devices, qualified lecturers are recruited, adequate provision of fund for provision of necessary amenities, adequate provision of curriculum and instructional materials, motivation of lecturers, adequate payment of entitlements, adequate provision of necessary infrastructures, provision of standby generator, equipment of laboratories, checking of class size and overcrowded school time table, payment of good salary with the notion that teachers are not well paid, many academics in Nigeria engage in other money making ventures, (Okorafor\&Ibeneme, 2015).

Irrespective of the global goals of SDGs and the implementation strategies, there are constraints/challenges to the attainment of SDGs by 2030. Educational projects need fund for their execution. Poor funding will deter the takeoff of the projects. Sometimes, the funds released for education may be embezzled or diverted to other projects. Large class size, curriculum overload, internet dissemination are obstructed, lack of information and misinformation are some of the problems that stagnate education (Ifeakor, 2009). Having read through the tasks ahead for the attainment of SDGs, the question one may ask now are how prepared are Library and Information Science lecturers to take up these responsibilities? What are the implementation strategies prepared for the Library and Information Science lecturers? What constraints is envisaged to challenge Library and Information Science lecturers' attainment of SDGs. The answers to these questions prompt the research for this study.

\subsection{Research Question}

The following research questions are posed to guide the study.

- How prepared are the LIS lecturers in Federal tertiary schools in Anambra State for the attainment of SDGs.

- What are the lecturers in Federal tertiary schools in Anambra State's perception on generating material resources for SDGs.

- What are the male and female LIS lecturers perception on the implementation strategies of SDGs

- What are the LIS Lecturers' perception on the envisaged barriers to the attainment of SDGs.

\subsection{Hypothesis}

There is no significant difference in the perception of the lecturers based on their institutional affiliation.

\subsection{Population of the Study}

The population of the study comprised all the lecturers found in the three Federal tertiary schools in Anambra State. Only library and Information Science Lecturers were used. The schools are: Federal Polytechnic Okoh, Federal College of Education (Technical) Umunze and Nnamdi Azikiwe University Awka

\subsection{Sample and Sampling Technique}

The sample constitutes all the 32 lecturers from the three Federal tertiary institutions in Anambra State offering library and Information Science in their school. The population size was obtained through personal visits and discussions with the relevant authorities in the schools. The entire population was studied without sampling.

\subsection{Instrument for Data Collection}

Data was collected using questionnaire. The questionnaire was made up of four-point scale ranging from Strongly Agree (SA), Agree (A), Disagree (DA), Strongly Disagree (SD), The data were analyzed using tables.

\subsection{Reliability of the Instrument}

The reliability co-efficient of the instrument was established using the Cronbach Alpha. The instrument was administered on a sample of 10 lecturers from Imo State University, Owerri. Reliability coefficient of 0.86 was established. 


\subsection{Administration of Instrument}

A total number of 32 copies of the questionnaire were distributed. All the distributed copies were returned indicating 100\% return rate. The data obtained were analyzed using mean. The hypotheses were tested using ANOVA statistic at 0.05 level of significance.

- Research Question 1: What are mean Rating scores of Library Information Science Lecturers' Preparedness for the Attainment of Sustainable Development Goals?

\begin{tabular}{|c|c|c|c|c|c|}
\hline $\mathbf{S} / \mathbf{N}$ & Item & $\mathbf{N}$ & Mean & SD & Decision \\
\hline 1 & provision of staff quarters for LIS lecturers & 32 & 1.41 & .87 & Disagree \\
\hline 2 & provision of refresher courses for LIS lecturers & 32 & 2.03 & 1.15 & Disagree \\
\hline 3 & $\begin{array}{c}\text { conferences, workshops seminars organized for LIS lecturers to } \\
\text { refresh their mind on the content of the curriculum }\end{array}$ & 32 & 1.59 & .91 & Disagree \\
\hline 4 & $\begin{array}{c}\text { LIS lecturers taught basic new trend in cataloguing, basic } \\
\text { technology in library science and virtual libraries }\end{array}$ & 32 & 2.00 & 1.05 & Agree \\
\hline 5 & $\begin{array}{c}\text { LIS lecturers are given better incentives motivation to score as } \\
\text { staff development }\end{array}$ & 32 & 2.19 & .69 & Disagree \\
\hline 6 & $\begin{array}{c}\text { LIS lecturers find it difficult to expose students to education for } \\
\text { life skills due to overcrowded school time-table }\end{array}$ & 32 & 3.06 & .84 & Agree \\
\hline 7 & $\begin{array}{c}\text { there is lack of learner-centered and activity - based teaching due } \\
\text { to large class size }\end{array}$ & 32 & 3.09 & .99 & Agree \\
\hline 8 & $\begin{array}{c}\text { LIS Lecturers are happy because they are sponsored to in-service } \\
\text { training on acquisition of new information, acquisition of new } \\
\text { skills and other required pedagogical strategies }\end{array}$ & 32 & 2.34 & 1.15 & Disagree \\
\hline 9 & $\begin{array}{c}\text { LIS lecturers face stress and classroom control problem in order } \\
\text { to cover over crowded library science curriculum }\end{array}$ & 32 & 3.13 & .833 & Agree \\
\hline 10 & $\begin{array}{c}\text { LIS lecturers are subjected to variety of subject matter content, } \\
\text { skills and techniques }\end{array}$ & 32 & 3.22 & .87 & Agree \\
\hline & $\quad$ Grand mean & 32 & 2.41 & .85 & Disagree \\
\hline
\end{tabular}

Table 1: Mean Rating of Library and Information Science Lecturers' on Preparedness for the Attainment of Sustainable Development Goals

As shown by the mean scores across the 10 items describing the Library Information Science Lecturers' Preparedness for the Attainment of Sustainable Development Goals in table 1, it is clear that the statements in items 1, 2, 3, 4,5 and 8 revealed disapproval of the statements by the respondents as library information science lecturers preparedness for the attainment of sustainable development goals. This is so because the mean values are less than the criterion midpoint of 2.50 while items 6, 79 and 10 received approval since their mean values are greater than the criterion midpoint. Results from the table using the grand mean of 2.41 revealed the Library Information Science Lecturers' Preparedness for the Attainment of Sustainable Development Goals

- Research question 2: what are the mean ratings of LIS lecturer's perception on generating material resources for SDGs?

\begin{tabular}{|c|c|c|c|c|c|}
\hline $\mathbf{S} / \mathbf{N}$ & Item & $\mathbf{N}$ & Mean & SD & Decision \\
\hline 1 & $\begin{array}{l}\text { funds are made available for the management of schools and library } \\
\text { materials }\end{array}$ & 32 & 2.59 & 1.19 & Agree \\
\hline 2 & $\begin{array}{c}\text { necessary equipment, facilities like furniture are provided for the hostels, } \\
\text { laboratories, and classrooms. }\end{array}$ & 32 & 1.81 & .86 & Disagree \\
\hline 3 & ICT laboratories, cataloguing laboratories have their separate laboratories. & 32 & 1.97 & .93 & Disagree \\
\hline 4 & $\begin{array}{l}\text { resource room are available for learning basic library ICT tools and } \\
\text { software in school. }\end{array}$ & 32 & 2.03 & 1.09 & Disagree \\
\hline 5 & $\begin{array}{l}\text { existing media laboratories are reactivated, modernized, furnished and } \\
\text { restructured for the teaching of online cataloguing and data uploading }\end{array}$ & 32 & 1.19 & .64 & Disagree \\
\hline 6 & $\begin{array}{l}\text { working/practical tools such as library of congress, marc 21, index card } \\
\text { cataloguing format, index tray are reactivated modernized and equipped } \\
\text { to be up to date }\end{array}$ & 32 & 1.09 & .29 & Disagree \\
\hline 7 & $\begin{array}{l}\text { old and archaic textbooks are weeded and older textbooks reviewed to be } \\
\text { complaint with the new curricula specifications of LIS }\end{array}$ & 32 & 1.72 & .89 & Disagree \\
\hline 8 & $\begin{array}{c}\text { New textbooks, journals, recruitment of staff, foreign and local magazines } \\
\text { and newspapers have been forwarded with new relevant materials for } \\
\text { basic library and information science as well as basic computer skill } \\
\text { acquisition and computer. }\end{array}$ & 32 & 1.00 & .00 & Disagree \\
\hline 9 & $\begin{array}{l}\text { community based library skills workshop and mobile library has been set } \\
\text { up or built in Anambra State }\end{array}$ & 32 & 1.03 & .18 & Disagree \\
\hline 10 & LIS curricula at the tertiary levels are digitized & 32 & 1.03 & .18 & Disagree \\
\hline 11 & $\begin{array}{l}\text { all the relevant infrastructures and equipment to usher in e-learning } \\
\text { activities are installed. }\end{array}$ & 32 & 1.12 & .34 & Disagree \\
\hline & Grand mean & 32 & 1.51 & .52 & Disagree \\
\hline
\end{tabular}

Table 2: Mean Ratings of LIS Lecturers Perception on Generating Material Resources for SDGs 
Table 3 shows that the statements in all the items in the table except items 12 and 13 are not LIS lecturers perception on generating material resources for SDGs, this is so because their mean values are less than the criterion midpoint value of 2.50. Results from the table using the grand mean of 1.51 revealed LIS lecturers perception on generating material resources for SDGs

- Research Question 3: what are the mean ratings of male and female LIS lecturer's perception on the implementation strategies of SDGs

\begin{tabular}{|c|c|c|c|c|c|c|}
\hline $\mathbf{S} / \mathbf{N}$ & Item & Gender & $\mathbf{N}$ & Mean & SD & Decision \\
\hline \multirow[t]{2}{*}{1} & $\begin{array}{l}\text { HODs receive training to prepare them for the } \\
\text { SDGs goals }\end{array}$ & Male & 10 & 1.60 & .52 & Disagree \\
\hline & & Female & 22 & 1.96 & 1.09 & Disagree \\
\hline \multirow[t]{2}{*}{2} & LIS lecturers are trained to be aware of SDGs & Male & 10 & 1.40 & .52 & Disagree \\
\hline & & Female & 22 & 1.73 & .83 & Disagree \\
\hline \multirow[t]{2}{*}{3} & $\begin{array}{l}\text { all hands of the tutorial and non-tutorial staff of } \\
\text { library and information science are on deck for the } \\
\text { attainment of SDGs }\end{array}$ & Male & 10 & 2.30 & .48 & Disagree \\
\hline & & Female & 22 & 2.18 & .79 & Disagree \\
\hline \multirow[t]{2}{*}{4} & $\begin{array}{l}\text { LIS lecturers are motivated to encourage them } \\
\text { through attractive condition of service }\end{array}$ & Male & 10 & 1.80 & .63 & Disagree \\
\hline & & Female & 22 & 2.09 & 1.19 & Disagree \\
\hline \multirow[t]{2}{*}{5} & more qualified staff are recruited & Male & 10 & 2.30 & .68 & Disagree \\
\hline & & Female & 22 & 2.41 & 1.09 & Disagree \\
\hline \multirow[t]{2}{*}{6} & $\begin{array}{l}\text { more fund are pumped into the education system } \\
\text { by authorities concerned }\end{array}$ & Male & 10 & 2.00 & .67 & Disagree \\
\hline & & Female & 22 & 2.18 & 1.29 & Disagree \\
\hline \multirow[t]{2}{*}{7} & LIS lecturers are not paid entitlement & Male & 10 & 1.00 & .00 & Disagree \\
\hline & & Female & 22 & 1.41 & .85 & Disagree \\
\hline \multirow[t]{2}{*}{8} & $\begin{array}{l}\text { all the stakeholder-government, philanthropist, } \\
\text { parents, community school, guardian are involved } \\
\text { in the attainment of SDGs goals }\end{array}$ & Male & 10 & 1.00 & .00 & Disagree \\
\hline & & Female & 22 & 1.46 & 1.01 & Disagree \\
\hline \multirow[t]{2}{*}{9} & $\begin{array}{l}\text { Computer and ICT gadget/devices are installed in } \\
\text { all the tertiary classrooms and admin offices and } \\
\text { laboratories. }\end{array}$ & Male & 10 & 1.00 & .00 & Disagree \\
\hline & & Female & 22 & 1.41 & .73 & Disagree \\
\hline \multirow[t]{2}{*}{10} & $\begin{array}{l}\text { Textbook writers and publishers are focused on } \\
\text { the content of the curriculum and are working } \\
\text { hard to ensure SDGs are attained }\end{array}$ & Male & 10 & 1.80 & .64 & Disagree \\
\hline & & Female & 22 & 2.10 & 1.23 & Disagree \\
\hline \multirow[t]{2}{*}{11} & $\begin{array}{l}\text { Necessary infrastructures and material resources } \\
\text { are available and provided }\end{array}$ & Male & 10 & 1.80 & .63 & Disagree \\
\hline & & Female & 22 & 2.05 & 1.17 & Disagree \\
\hline \multirow[t]{2}{*}{12} & Stand by generators are provided to avoid light off & Male & 10 & 2.40 & .52 & Disagree \\
\hline & & Female & 22 & 2.68 & .95 & Agree \\
\hline \multirow[t]{2}{*}{13} & Absence of power cut, and adequate water supply & Male & 10 & 2.60 & 1.08 & Agree \\
\hline & & Female & 22 & 2.73 & 1.24 & Agree \\
\hline
\end{tabular}

Table 3: Mean Ratings of Male and Female LIS Lecturer's Perception on the Implementation Strategies

Table 3 shows the ratings of male and female LIS lecturers' perceptions on implementation strategies of SDGs. The result shows among the 13 items, only item 12 for female only and item 13 for both male female were agreed by respondents as implementation strategies of SDGs. This is so because their mean values are greater than the criterion mean point of 2.50. While other items were disagreed since the mean values are less than 2.50 criterion mean point.

- $\quad$ Research Question 4: What is the Mean Rating on LIS Lecturers' Perception on the Envisaged Challenges to the Attainment of SDGs 


\begin{tabular}{|c|c|c|c|c|c|}
\hline $\mathbf{S} / \mathbf{N}$ & Item & $\mathbf{N}$ & Mean & SD & Decision \\
\hline 1 & there is paucity of fund & 32 & 2.19 & 1.18 & Disagree \\
\hline 2 & $\begin{array}{l}\text { distortion, corruption, mismanagement and } \\
\text { embezzlement of fund pose changes }\end{array}$ & 32 & 2.13 & 1.13 & Disagree \\
\hline 3 & there is dearth of LIS lecturers & 32 & 2.75 & .92 & Agree \\
\hline 4 & $\begin{array}{c}\text { there is paucity of training and retraining } \\
\text { lecturers for better performance }\end{array}$ & 32 & 2.03 & 1.15 & Disagree \\
\hline 5 & there is lack of lecturers motivation & 32 & 2.78 & 1.16 & Agree \\
\hline 6 & there is pauscity of material resources & 32 & 2.78 & 1.16 & Agree \\
\hline 7 & the class size is too large & 32 & 2.84 & 1.11 & Agree \\
\hline 8 & curriculum content is too voluminous & 32 & 2.84 & 1.11 & Agree \\
\hline 9 & lack of communication flow from top to bottom & 32 & 3.09 & .86 & Agree \\
\hline 10 & $\begin{array}{c}\text { there is pauscity of ICT facilities and ICT } \\
\text { laboratories to support full application of library } \\
\text { technology }\end{array}$ & 32 & 2.94 & .84 & Agree \\
\hline 11 & irregular power supply is a challenge & 32 & 2.97 & .82 & Agree \\
\hline 12 & $\begin{array}{l}\text { insufficient and incompetent qualified lecturers } \\
\text { pose challenge. }\end{array}$ & 32 & 2.84 & .85 & Agree \\
\hline & Grand mean & & 2.68 & .98 & Agree \\
\hline
\end{tabular}

Table 4: Mean Ratings on LIS Lecturers' Perception on the Envisaged Challenges to the Attainment of SDGs

As shown by the mean scores across the 12 items describing the Rating on LIS Lecturers' Perception on the Envisaged Challenges to the Attainment of SDGs in table 4, all the items except items 1, 2 and 4 are approved by the respondents as LIS Lecturers' Perception on the Envisaged Challenges to the Attainment of SDGs. This is so because the mean values are greater than the criterion midpoint of 2.50. Results from the table using the grand mean of 2.2 .68 revealed the LIS Lecturers' Perception on the Envisaged Challenges to the Attainment of SDGs

- Hypothesis 1: there is no significant difference in the perception of the lecturers based on their institutional affiliation.

\begin{tabular}{|c|c|c|c|c|c|c|}
\hline & $\begin{array}{c}\text { Sum of } \\
\text { Squares }\end{array}$ & df & $\begin{array}{c}\text { Mean } \\
\text { Square }\end{array}$ & F & Sig. & Decision \\
\hline $\begin{array}{c}\text { Between } \\
\text { Groups }\end{array}$ & 12.157 & 2 & 6.078 & 25.363 & .000 & Significant \\
\hline $\begin{array}{c}\text { Within } \\
\text { Groups }\end{array}$ & 6.950 & 29 & .240 & & & \\
\hline Total & 19.107 & 31 & & & & \\
\hline
\end{tabular}

Table 5: ANOVA Table for the Significant Difference of the Lecturers' Perception

Based on Their Institutional Affiliation

The result in the table 5 shows that there is a statistically significant difference in lecturers perception based on their institutional affiliation. This is so because, the p-value .000 is less than the level of significant 0.05 ; the researcher therefore rejected the null hypothesis and concluded that there is a statistically significant difference in lecturers perception based on their institutional affiliation.

\section{Discussion and Major Findings}

The result of this study has revealed that lecturers agreed that they are not yet motivated for staff development, subjected to pressure in order for them to cover the overcrowded, Library Science Curriculum and school time table.

Library and Information Science Lecturers non-acceptance that they are motivated for staff development could be as a result of their non-sponsor to neither workshops professional conferences nor maybe they are encouraged to attend other conferences and in service training for them to acquire new skill.

This findings is in line with Hill (2012) in which he noted that Administrators should encourage their teachers to continue their education as well as make opportunities available for them to do so moreover, administrators and districts should offer to either pay or help pay for the classes and workshops.

The result of the study showed that sufficient funds are not provided for the administration of schools. Lack of adequate material resources are suffered. Textbooks domiciled in the schools are yet to comply with the new curricula requirements of LIS. There are no media laboratories with basic ICT devices, some infrastructures such as, classrooms hostels, up to date media laboratories are yet to be built while some schools have a separate library with outdated material which is non-compliant with the new curriculum.

For the training of HODs, Lectures, Motivation of Library and Information Science Lecturers and effort to involve the stakeholders and philanthropists in the activities for the attainment of the SDGs is very necessary, it was discovered that male and female Library and Information Science Lecturers have mapped out implementation strategies to focus their attention on it. It also revealed that all other implementation strategies are yet to be attained. It also shows that male and female library and information science lecturers were thinking that for the SDGs to be attained that all the infrastructure 
and facilities would be on the ground. Infrastructure and material resources textbooks, electricity-Generator, water supply and curricular materials are all required.

It is glaring that lack of fund; poor electric power supply is among the major barriers to the attainment of SDGs. In order for the identified barriers to be solved,

- More fund should be provided by the government and stalk holders for the management of the schools.

- The findings of the study, revealed that library and Information Science Lecturers agree to the introduction of global reforms and the attainment of SDGs. Looking at the expectations for attainment of SDGs, authors noted that the provision of relevant and functional resources for LIS education will help to boost the effective delivery of LIS curriculum content and that non provision will create a gap and also become an impediment for educational reforms.

- In the light of the above, for LIS lecturers to effectively attain SDGs, the policy makers and stakeholders in LIS profession would need to address the following issues:

- Efforts should be focused on retraining serving Lecturers to be SDGs compliant.

- Efforts should be made by the stakeholders and policy makers at all levels to develop new relevant textual materials for library and information science education.

- Government should as a matter of priority provide laboratories or resource rooms for learning technical service courses and ICT courses.

- The existing ICT, cataloguing laboratories and media laboratories should be improved and reactivated to enhance teaching and learning pedagogy in LIS education.

- They should allocate sufficient fund to support library services and management.

- Efforts should be made to ensure information flow from top to bottom and from bottom to top (Free from information overload)

- Overcrowding occasioned by inadequate space in the classroom should be tackled.

- Bodies involved in SDGs should have a working relation with the various library schools and other departments for SDGs programmes and activities to be introduced to lecturers and students in their schools.

- There is great need to continuously educate and enlighten the lecturers on the importance of SDGs and the need for total compliance.

\section{References}

i. Adegbulu, A. (n.d). The 17 sustainable development goals and targets. Retrieved from https://adesojiadegbulu .com.>su...

ii. Armeanu, O.S., Vintila, G. \&Gherghina, S.C. (2017). Empirical study towards the drivers of sustainable economic growth in EU-28 countries. Retrieved from www.htt://

iii. Ayomike, C.S., Okwelle, P.C. \&Okeke B.C. (2015). Information and Communication Technology (ICT) for effective delivery in technical education: Delta State University experience. International Journal of Educational Research and Development, (IJERD) 5(1) 109-120.

iv. Crespo, B., Miguez-Alvarez, C., Arce, M.E., Cueras, M. \&Miguez, J.L. (2017). The sustainable development goals: an experience on higher education. Retrieved from http://creativecommons.org/licenses/by/4.01

v. Dushi, G. (2012). Need and importance of curriculum. Retrieved fromhttp://www.Preservearticles.com/201201092.

vi. Hill, E. F. (2012). Refocusing tertiary education in Nigeria: The SDGs perspective, in Mbadugha S.M. Madu, P.I. \&Tamuno, G.T. (Eds), Refocusing education in Nigeria. Akwalbom, Nigeria: Daniel influence.

vii. Ifeakor, A.C. (2009). Science teachers' perception on generating resources for attaining millennium development goals in Anambra State. UNIZIK Journal of Science Education 1 (1) 85-95.

viii. IIEP-UNESCO (2016). The challenges for higher education and the SDGs. Retrieved from https: www.iiep.unesco. org.

ix. Obioma, G.O. (2006). Resources for Science Technology and Mathematics Education (STME) in the context of Education Reforms in Nigeria: Key note Address 47th Proceedings of STAN Conference 3 - 7.

x. Ogbuigwe, A. (2017). Advancing sustainability in higher education through the UN's Sustainable Development Goals. Retrieved from sustainability. mitiedu/ort.

xi. Okorafor, O.A. \&Ibeneme, O.T. (2015). Ethical issues in teaching and learning of vocational education in Nigeria. International Journal of Educational Research and Development, (IJERD) 5(1), 165-171.

xii. www.Ibe.unisco.org/en/glossary-curr... 